\title{
Analysis of hypermethylation and expression profiles of $A P C$ and ATM genes in patients with oral squamous cell carcinoma
}

\author{
Mohammad Ayub Rigi-Ladiz', Dor Mohammad Kordi-Tamandani² ${ }^{*}$ and Adam Torkamanzehi
}

\begin{abstract}
Background: Adenomatous polyposis coli (APC) and Ataxia-telangiectasia-mutated (ATM) gene products have an important role in cell cycle control and maintenance of genomic stability. Our aim was to analyze ATM and APC methylation and its relationship with oral squamous cell carcinoma (OSCC).

Materials and methods: Eighty-four OSCC tissues that have been fixed in paraffin along with 57 control oral samples have been used for analyzing promoter methylation of ATM and APC genes by Methylation Specific Polymerase Chain Reaction (MS-PCR). In addition, 10 cases of OSCC and the same of matched controls were examined for estimating expression of the above mentioned genes using Real-Time Reverse-Transcription PCR.

Results: Observed promoter methylations were $71.42 \%$ and $87.71 \%$ for the APC gene and $88.09 \%$ and $77.19 \%$ for the ATM gene in cases and controls, respectively. Analysis of these data showed that promoter methylation at APC was significantly different in cases compared to healthy controls $(p=0.01)$, but no difference was detected for the ATM gene. Furthermore, the mRNA expression levels did not differ statistically between cases and controls for both ATM (cases $=9$, controls $=10$ ) and APC (cases $=11$, controls $=10$ ) genes.
\end{abstract}

Conclusions: Our results, for the first time, provide methylation profiles of ATM and APC genes in a sample of patients with OSCC in a southeast Iranian population. The present data support related evidence of APC methylation effect on OSCC development.

Keywords: OSCC, ATM, APC, DNA methylation, gene expression

\section{Introduction}

Oral squamous cell carcinoma (OSCC) is one of the most frequently diagnosed types of head and neck cancers based on epidemiological reports [1]. It has been suggested that OSCC can arise in the course of accumulation of multiple genetic alterations [2], for which accurate molecular mechanisms regarding its pathogenesis remain to be understood.

In addition to genetic changes, any alteration in epigenetic information such as DNA methylation, histone modifications, chromatin structure, microRNA, and other genomic functions may make an individual susceptible to developing cancer [3]. Hyper-methylation of promoter $\mathrm{CpG}$ islands and repetitive DNA sequences

\footnotetext{
* Correspondence: dor_kordi@yahoo.com

${ }^{2}$ Department of Biology, University of Sistan and Baluchestan, Zahedan, Iran Full list of author information is available at the end of the article
}

has been recognized as one of the most important variations in the progression of the cancer [4]. Growing data points to the critical role of CpG island hypermethylation in genes implicated in apoptosis, cell cycle regulation, and cellular differentiation in various types of cancer [5,6]. In respect to OSCC development, current studies show that epigenetic silencing of cancer-linked genes through DNA methylation plays a significant role $[7,8]$. In the genomes of mammals, methylation takes place at $\mathrm{CpG}$ islands that are located in the promoter region of approximately half of the genes. These are heritable throughout mitosis and are copied to the new strand by DNA methylatransferase-1 during DNA replication [9]. Although the accurate function of DNA methylation in OSCC is not fully understood, it is well known that gene expression is influenced by DNA methylation. Overall, DNA methylation represses 
transcription, and loss of methylation restores gene activation [10].

In this study, we examined hypermethylation of ataxia-telangiectasia-mutated (ATM) and adenomatous polyposis coli (APC) genes and their expression profiles in patients with OSCC.

ATM gene is located on chromosome 11q22-23[11], and encodes a serine-threonine kinase that belongs to the phosphatidylinositol-3 kinase (PI-3K) family. This enzyme plays an essential role in the pathways activated by DNA breaks [12]. In reaction to various agents that damage DNA, ATM phosphorylates p53, which increases its stabilization and expression level, ultimately leading to cell cycle arrest, DNA repair, and apoptosis[13]. However, the possible link between p53 and ATM deactivation in the expansion and development of human tumors is not well established. A number of groups have identified the 11q22-23 locus as a common deletion site in head and neck squamous cell carcinoma (HNSCC)[14]. However, it is presently unclear whether ATM is exhibiting this deletion in the HNSCCs, because this protein has an important role in preserving genomic homeostasis in HNSCC and other types of cancers $[15,16]$.

APC gene is located on chromosome 5q21-q22 and encodes a homodimeric protein that functions in the cytoplasm and nucleus of the cells and has an important role in cell cycle arrest and apoptosis [17]. The wildtype APC protein acts as a vital controller in the Wntsignaling pathway [18]. A relationship between methylation of CpG sites of $A P C$ gene and different types of cancer have recently been observed $[19,20]$. However, the associations of APC and ATM genes' methylation with gene silencing mechanisms have not yet been fully elucidated. The aim of our study was to investigate the effect of hypermethylation of APC and ATM genes and their expression profile in patients with OSCC.

\section{Results}

\section{Detection of methylation in APC and ATM genes using} MS-PCR

Results of the APC and ATM genes methylation status in patients with OSCC and healthy individuals and their relationship with clincopathalogical parameters are shown in Tables 1 and 2. There was no significant association between methylation status of ATM and APC and clinical parameters such as sex, age, and tumor stages. As shown in table 3, methylation of ATM was found in $88.09 \%$ (74 out of 84 ) of patients with OSCC and in $77.19 \%$ (44 out of 57 ) of healthy controls. Similarly, APC gene methylation was $71.42 \%$ (60 out of 84 ) in cases and $87.71 \%$ (50 out of 57) in controls. Comparison of methylation status between cases and controls revealed statistically significant differences for APC $(\mathrm{p}=$ 0.01 ) and insignificant for ATM. This part of result has been analyzed by $\chi 2$ and $t$ tests.

\section{Analysis of relative APC and ATM genes expression}

Analysis of relative gene expression $\left(2^{-\Delta \Delta C T}\right)$ for APC and ATM between cases and controls was done by Mann-Witny test. As shown in Table 4, APC relative

Table 1 Relationship between APC promptor methylation and clinicopathology parameters in healthy controls and cases

\begin{tabular}{|c|c|c|c|c|c|c|c|c|}
\hline \multirow[t]{2}{*}{ Characteristics } & \multirow{2}{*}{$\begin{array}{l}\text { Controls } \\
\mathrm{N}=57\end{array}$} & \multicolumn{2}{|c|}{ * APC Methylation status } & \multirow[t]{2}{*}{$P$ value } & \multirow{2}{*}{$\begin{array}{l}\text { Cases } \\
\mathrm{N}=84\end{array}$} & \multicolumn{2}{|c|}{$A P C$ methylation status } & \multirow{2}{*}{$\begin{array}{l}{ }^{* * P} \\
\text { value }\end{array}$} \\
\hline & & $\begin{array}{l}\text { Present } \\
\mathrm{N}(\%)\end{array}$ & $\begin{array}{l}\text { Absent } \\
\mathrm{N}(\%)\end{array}$ & & & $\begin{array}{l}\text { Present } \\
\text { N (\%) }\end{array}$ & $\begin{array}{l}\text { Absent } \\
\mathrm{N}(\%)\end{array}$ & \\
\hline Mean age & $39.07 \pm 14$ & & & & $54.14 \pm 18$ & & & \\
\hline \multirow[t]{2}{*}{$<50$} & 46 & $39(84.8)$ & $7(15.2)$ & & 26 & $20(76.93)$ & $6(23.07)$ & \\
\hline & & & & 0.9 & & & & 0.2 \\
\hline$>50$ & 11 & 10(90.90) & $1(9.1)$ & & 58 & $39(67.24)$ & 19(32.76) & \\
\hline \multicolumn{9}{|l|}{ Sex } \\
\hline \multirow[t]{2}{*}{ Male } & 21 & $18(85.7)$ & $3(14.3)$ & & 39 & $32(82.05)$ & $7(17.95)$ & \\
\hline & & & & 0.06 & & & & 0.72 \\
\hline Female & 36 & $32(88.88)$ & $4(11.12)$ & & 45 & $28(62.22)$ & 17(37.78) & \\
\hline Stage & & & & & & & & 0.05 \\
\hline । & - & - & - & - & 18 & $11(61.11)$ & 7(38.89) & \\
\hline$\|$ & & & & & 18 & 15(83.33) & $3(16.64)$ & \\
\hline III & & & & & 43 & $31(72.08)$ & 12(27.92) & \\
\hline IV & & & & & 5 & $2(40)$ & $3(60)$ & \\
\hline
\end{tabular}

* Methylation present: means that PCR product is produced only with methylated primers. Methylation absent: means that PCR product is produced only with unmethylated primers. ${ }^{* *}$ Chi-square test 
Table 2 Relationship between ATM promptor methylation and clinicopathology parameters in healthy controls and cases

\begin{tabular}{|c|c|c|c|c|c|c|c|c|}
\hline \multirow[t]{2}{*}{ Characteristics } & \multirow{2}{*}{$\begin{array}{l}\text { Controls } \\
\mathrm{N}=57\end{array}$} & \multicolumn{2}{|c|}{ ATM methylation status } & \multirow[t]{2}{*}{$P$ value } & \multirow{2}{*}{$\begin{array}{l}\text { Cases } \\
\mathrm{N}=84\end{array}$} & \multicolumn{2}{|c|}{ ATM methylation status } & \multirow{2}{*}{$\begin{array}{l}{ }^{* P} \\
\text { value }\end{array}$} \\
\hline & & $\begin{array}{l}\text { Present } \\
\mathrm{N}(\%)\end{array}$ & $\begin{array}{l}\text { Absent } \\
\mathrm{N}(\%)\end{array}$ & & & $\begin{array}{l}\text { Present } \\
\mathrm{N}(\%)\end{array}$ & $\begin{array}{l}\text { Absent } \\
\mathrm{N}(\%)\end{array}$ & \\
\hline Mean age & $39.07 \pm 14$ & & & & $54.14 \pm 18$ & & & \\
\hline$<50$ & 46 & $36(78.26)$ & $10(21.74)$ & 0.3 & 26 & 23(88.46) & $3(11.54)$ & 0.103 \\
\hline$>50$ & 11 & $8(72.72)$ & $3(27.28)$ & & 58 & $51(87.93)$ & $7(12.07)$ & \\
\hline \multicolumn{9}{|l|}{$\overline{\text { Sex }}$} \\
\hline Male & 21 & 17(80.95) & $4(19.05)$ & 0.6 & 40 & $34(85)$ & $6(15)$ & 0.404 \\
\hline Female & 36 & $27(75)$ & $9(25)$ & & 44 & 40(90.90) & $4(9.1)$ & \\
\hline \multicolumn{9}{|l|}{$\overline{\text { Stage }}$} \\
\hline । & & & & & 18 & 16(88.88) & $2(11.12)$ & 0.465 \\
\hline$\|$ & - & - & - & - & 18 & 15(83.32) & $3(16.68)$ & \\
\hline III & & & & & 43 & $38(83.36)$ & $5(11.64)$ & \\
\hline IV & & & & & 5 & $5(100)$ & 0 & \\
\hline
\end{tabular}

*Chi-square test

expression was $2.06 \pm 2$ for cases $(\mathrm{n}=11$, range: $0.004-$ $7.4)$ and $0.95 \pm 1.31$ for controls $(n=10$, range: 0.002 3.43). The ATM data were $0.5 \pm 0.9$ for cases $(n=9$, range: $0.005-2.94)$ and $1.48 \pm 2.2$ for controls $(n=10$, range: $0.0001-6.27)$. The difference was not statistically significant between patients and healthy individuals.

\section{Discussion}

In this study, our results indicated a significant difference in methylation profile between cases and controls for APC gene $(p=0.01)$, but not for ATM.

In recent years, gene expression, as well as other molecular profiling, has been used as biological tools for diagnosis of cancer $[21,22]$. These molecular approaches also have the potential to explore molecular mechanisms of the disease and to pave the road to targeted cancer fighting drugs and advanced treatments [23]. APC is one the most important elements of the Wnt-signaling pathway; its activation is a general characteristic of solid tumors such as bladder, prostate, and renal tumors. Epigenetic down regulation of Wnt pathway inhibitors may contribute to aberrant activation of Wnt signaling pathway [24]. Hypermethylation of APC promoter can silence

Table 3 Comparison of promoter methylation of APC and ATAM genes in patients with oral cavity cancer and healthy controls

\begin{tabular}{lllll}
\hline Gene & Methylation statuse & $\begin{array}{l}\text { Controls } \\
\text { N (\%) }\end{array}$ & $\begin{array}{l}\text { Cases } \\
\text { N (\%) }\end{array}$ & *P value \\
\hline APC & Present & $50(87.71)$ & $60(71.42)$ & 0.01 \\
& Absent & $7(12.29)$ & $24(28.58)$ & \\
\hline ATM & Present & $44(77.19)$ & $74(88.09)$ & 0.8 \\
& Absent & $13(22.81)$ & $10(11.91)$ & \\
\hline
\end{tabular}

${ }^{*}$ Chi-square test gene expression by interfering with the binding of transcription factors to the promoter [25]. According, with our results, Uesugi and his colleagues have reported that inactivation of the APC gene via hypermethylation has a significant role in oral carcinogenesis [26].

Jing et al., (2010) have also reported an association between hypermethylation of APC gene promoter and breast cancer [27]. Furthermore, there are reports that APC promoter hypermethylation is linked with $H$. pylori-associated gastritis [28], cervical cancer [29], and esophageal adenocarcinoma [30]. While our observations support the connection between APC hypermethylation with OSCC progression, this study did not find any significant change in APC expression levels between patients and controls. One explanation for these observation may be due to the involvement of other factors which reducee gene expression. Also, since the number of tumor and control samples analyzed was relatively small it was not enough to establish a strong and significant relationship between hypermethylation and gene expression for these genes. Further analysis involving larger sample sizes are needed to elucidate this matter.

Table 4 Comparison of gene expression levels $\left(2^{-\Delta \Delta C T}\right)$ of $A T M$ and $A P C$ between patients with oral cavity cancer and healthy controls.

\begin{tabular}{lllll}
\hline Gene & & N & Mean \pm SD & P-value (Mann-Whitney test) \\
\hline APC & Cases & 11 & $2.06 \pm 2.6$ & 0.3 \\
\cline { 2 - 4 } & Controls & 10 & $0.95 \pm 1.31$ & \\
\multirow{2}{*}{ ATM } & Cases & 9 & $0.5 \pm 0.9$ & 0.9 \\
\cline { 2 - 3 } & Controls & 10 & $1.48 \pm 2.2$ & \\
\hline
\end{tabular}


Table 5 Primer sequences and annealing temperature

\begin{tabular}{|c|c|c|}
\hline Genes & Sequences & $\begin{array}{l}\text { Annealing } \\
\text { temperature }\end{array}$ \\
\hline$A P C M$ & $\begin{array}{l}\text { F:GAACCAAAACGCTCCCCAT } \\
\text { R:TTATATGTCGGTTACGTGCGTTATAT }\end{array}$ & 61 \\
\hline$\overline{A P C U}$ & $\begin{array}{l}\text { F:AAACCAAAACACTCCCCATTC } \\
\text { R:AGTTATATGTTGGTTATGTGTGTTTAT }\end{array}$ & 56 \\
\hline ATM M & $\begin{array}{l}\text { F:GGAGTTCGAGTCGAAGGG } \\
\text { R:CTACCTACTCCCGCTTCCGA }\end{array}$ & 65 \\
\hline ATM U & $\begin{array}{l}\text { F:GTITTGGAGTTTGAGTTGAAGGGT } \\
\text { R:AACTACCTACTCCCACTTCCAA }\end{array}$ & 60 \\
\hline GAPDH (Real Time-PCR) & $\begin{array}{l}\text { F: CCACTCCTCCACCTTTGAC } \\
\text { R: ACCCTGTTGCTGTAGCCA }\end{array}$ & 60 \\
\hline APC(Real Time-PCR) & F:CTTCAAAATTACCTCCAC R:CTCCTCTAACTCCTTCTC & 60 \\
\hline ATM(Real Time-PCR) & F:CAGGGTAGTTAAGTGAG GTTGACAG R:CTATACTGGTGGTCAGTGCCAAAGT & 60 \\
\hline
\end{tabular}

ATM gene is a component of the PI3 kinase family, which is vital in signaling pathways of DNA damage. ATM kinase activates and phosphorylates a number of downstream regulatory proteins that are significant in apoptosis, DNA repair, and cell cycle arrest [31]. Various reports have shown the association of ATM mutation with risk of different human malignancies including breast, prostate, and ovarian cancers, mantle cell lymphoma, and B-cell chronic lymphocytic leukemia. The primary molecular pathway(s) by which ATM gene leads to these alterations are not well known [32]. So far, no study has shown strict involvement of ATM gene methylation with OSCC.

The results of Wai et al., (2004) indicated 45\% hypermethylation of ATM gene in fecal DNA of patients with colorectal cancer and its lack in healthy controls [33]. This has the potential to be used as predictive factor for patients with non-small cell cancer [34] and thyroid carcinoma [35].

Vo QN et al., (2004) showed a link between decreased ATM function due to epigenetic silencing and sporadic breast malignancy [36]. On the contrary, a study on a full range of B-cell lines with variable degrees of differentiation showed that methylation of ATM gene is far less frequent in lymphomagenesis compared to deletions and mutations [37].

DNA methylation and histone modification emerge to work together to silence the expression of a number of genes in cancer, such as APC and hMLH1 [25,38]. However, our study has some limitations, it has been focus on analysis of 2 genes so, identification of further novel CpG islands that are specifically linked with OSCC will be needed to create a panel with higher sensitivity that maintains high specificity, and studies examining detection of such a panel of genes by newly developed quantitative assays should be undertaken.

Obviously, additional studies are needed to further elucidate the relationship between DNA methylation, demethylation, and histone modification in genes regulation. Results from such research may support new strategies and suggest further study with larger sample size for better understanding of molecular mechanisms of cancer, which play a critical role in prevention and management of disease.

\section{Materials and methods}

\section{Samples and DNA preparation}

Eighty-four OSCC tissues that had been fixed in paraffin along with 57 control oral mucosa were collected from patients without history of OSCC who were referred to Periodontics Department, Dental School, Zahedan University of Medical Sciences. All procedures in this study were approved by the Ethical Board at the Zahedan University of Medical Sciences. Genomic DNA was extracted using QIAamp DNA Kits from cancerous (Cat. No. 56404, Qiagen) and healthy control (Cat. No.51304, Qiagen) samples, and then its quality was estimated by a spectrophotometer.

Methylation-Specific Polymerase Chain Reaction (MS-PCR) The process of bisulfite conversion of DNA sampleswas conducted as previously described [39]. MSP analysis of promoter regions of $A P C$ and $A T M$ was carried out in $25 \mu \mathrm{l}$ PCR reactions containing $1 \mu \mathrm{l}$ of bisulfite-treated genomic DNA, oligonucleotide primers (25 pmol each/ reaction), dNTPs (200 $\mu \mathrm{M}$ each), 0.625 units of Hotstar Taq (Qiagen, Valencia, CA) in $1 \times$ PCR buffer and 2.5 $\mathrm{mM} \mathrm{MgCl} 2$. Thermo cycling conditions were carried out using the following settings: $95^{\circ} \mathrm{C}$ for $10 \mathrm{~min} ; 40$ cycles consisting of $\left[30 \mathrm{~s}\right.$ at $95^{\circ} \mathrm{C}, 30 \mathrm{~s}$ at $61^{\circ} \mathrm{C}$ for $\mathrm{APC}$ (M), $56^{\circ} \mathrm{C}(\mathrm{U})$ and for ATM $65^{\circ} \mathrm{C}(\mathrm{M}), 60^{\circ} \mathrm{C}(\mathrm{U}), 1 \mathrm{~min}$ at $72^{\circ} \mathrm{C}$ ], and a final extension at $72^{\circ} \mathrm{C}$ for $10 \mathrm{~min}$. Parallel with each set of MSP reactions, positive and negative controls were run. Ten microliters of each MSP reactions were electrophoresed on $3.5 \%$ agarose gels and were visualized by ethidium bromide staining. The list of primers were utilized are giving in Table 5 . 


\section{Reverse transcription-PCR analysis of $A P C$ and $A T M$} We extracted total RNA from OSCC and control tissues using the High pure RNA Tissue kit (Cat No: 12033674001) and High pure FFPE RNA Micro kit (Cat No: 04823125001), respectively, according to the manufacturer's instructions. The cDNA synthesis kit (Cat No: K1611, Frmantase) was used for converting $1 \mu \mathrm{g}$ of total RNA to cDNA according to the manufacturer's instructions. Real time-PCR of APC, ATM, and glyceraldehyde-3-phosphate dehydrogenize (GAPDH) were performed using SYBR green assay by 7300 Real-Time PCR System (Applied Biosystems, Foster City, CA).

\section{Statistical analysis}

Analysis of data was carried out using SPSS software version 17.0 to evaluate association between methylation status of APC and ATM genes and clinical parameters by $\chi 2$ and $t$ tests. Assaying relative gene expression $\left(2^{-}\right.$ $\triangle \Delta \mathrm{CT}$ ) between cases and controls were done by MannWhitney test. Significance level was set at $\mathrm{P}<0.05$ for all tests.

\section{Acknowledgements}

This work was supported by joint research grants from the University of Sistan and Baluchestan (USB) and Zahedan University of Medical Sciences (ZUMS) to D.M.K.T., A. T. and M.Y.R.L. We sincerely acknowledge maintenance support from USB's Department of Biology.

\section{Author details}

'Department of Periodontics, Dental School, Zahedan University of Medical Sciences, Zahedan, Iran. ${ }^{2}$ Department of Biology, University of Sistan and Baluchestan, Zahedan, Iran.

\section{Authors' contributions}

MR: participated in providing samples, DK: Carried out the molecular genetic studies, the design of the study and the statistical analysis. AT: Participated in its design and coordination. Finally, all authors read and approved the final manuscript.

\section{Competing interests}

The authors declare that they have no competing interests.

Received: 8 June 2011 Accepted: 1 November 2011 Published: 1 November 2011

\section{References}

1. Parkin DM, Bray F, Ferlay J, Pisani P: Global cancer statistics, 2002. CA Cancer J Clin 2005, 55(2):74-108.

2. Sogabe $Y$, Suzuki H, Toyota M, Ogi K, Imai T, Nojima M, et al: Epigenetic inactivation of SFRP genes in oral squamous cell carcinoma. Int $J$ Oncol 2008, 32(6):1253-61.

3. Kouzarides T: Chromatin modifications and their function. Cell 2007, 128(4):693-705.

4. Feinberg AP, Ohlsson R, Henikoff $S$ : The epigenetic progenitor origin of human cancer. Nat Rev Genet 2006, 7(1):21-33.

5. Jones PA, Baylin SB: The fundamental role of epigenetic events in cancer. Nat Rev Genet 2002, 3(6):415-28.

6. Fazzari MJ, Greally JM: Epigenomics: beyond CpG islands. Nat Rev Genet 2004, 5(6):446-55.

7. Ha PK, Califano JA: Promoter methylation and inactivation of tumoursuppressor genes in oral squamous-cell carcinoma. Lancet Oncol 2006, 7(1):77-82.
8. Ogi K, Toyota M, Ohe-Toyota M, Tanaka N, Noguchi M, Sonoda T, et al: Aberrant methylation of multiple genes and clinicopathological features in oral squamous cell carcinoma. Clin Cancer Res 2002, 8(10):3164-71.

9. Flanagan JM, Munoz-Alegre M, Henderson S, Tang T, Sun P, Johnson N, et al: Gene-body hypermethylation of ATM in peripheral blood DNA of bilateral breast cancer patients. Hum Mol Genet 2009, 18(7):1332-42.

10. Irvine RA, Lin IG, Hsieh C-L: DNA methylation has a local effect on transcription and histone acetylation. Mol Cell Biol 2002, 22(19):6689-96.

11. Barr FG, Chatten J, D'Cruz CM, Wilson AE, Nauta LE, Nycum LM, et al: Molecular assays for chromosomal translocations in the diagnosis of pediatric soft tissue sarcomas. Jama 1995, 273(7):553-7.

12. Wu X, Ranganathan V, Weisman DS, Heine WF, Ciccone DN, O'Neill TB, et al: ATM phosphorylation of Nijmegen breakage syndrome protein is required in a DNA damage response. Nature 2000, 405(6785):477-82.

13. Wang JY: Regulation of cell death by the Abl tyrosine kinase. Oncogene 2000, 19(49):5643-50.

14. Lese CM, Rossie KM, Appel BN, Reddy JK, Johnson JT, Myers EN, et al: Visualization of INT2 and HST1 amplification in oral squamous cell carcinomas. Genes Chromosomes Cancer 1995, 12(4):288-95.

15. Ai L, Vo QN, Zuo C, Li L, Ling W, Suen JY, et al: Ataxia-telangiectasiamutated (ATM) gene in head and neck squamous cell carcinoma: promoter hypermethylation with clinical correlation in 100 cases. Cancer Epidemiol Biomarkers Prev 2004, 13(1):150-6.

16. Camacho E, Hernandez L, Hernandez S, Tort F, Bellosillo B, Bea S, et al: ATM gene inactivation in mantle cell lymphoma mainly occurs by truncating mutations and missense mutations involving the phosphatidylinositol-3 kinase domain and is associated with increasing numbers of chromosomal imbalances. Blood 2002, 99(1):238-44.

17. Browne SJ, Williams AC, Hague A, Butt AJ, Paraskeva C: Loss of APC protein expressed by human colonic epithelial cells and the appearance of a specific low-molecular-weight form is associated with apoptosis in vitro. Int J Cancer 1994, 59(1):56-64

18. Ilyas M, Straub J, Tomlinson IP, Bodmer WF: Genetic pathways in colorectal and other cancers. Eur J Cancer 1999, 35(3):335-51.

19. Brabender J, Usadel H, Danenberg KD, Metzger R, Schneider PM, Lord RV, et al: Adenomatous polyposis coli gene promoter hypermethylation in non-small cell lung cancer is associated with survival. Oncogene 2001, 20(27):3528-32.

20. Deng G, Song GA, Pong E, Sleisenger M, Kim YS: Promoter methylation inhibits APC gene expression by causing changes in chromatin conformation and interfering with the binding of transcription factor CCAAT-binding factor. Cancer Res 2004, 64(8):2692-8.

21. Pinyol M, Hernandez L, Martinez A, Cobo F, Hernandez S, Bea S, et al: INK4a/ARF locus alterations in human non-Hodgkin's lymphomas mainly occur in tumors with wild-type p53 gene. Am J Pathol 2000, 156(6):1987-96.

22. Bea S, Ribas M, Hernandez JM, Bosch F, Pinyol M, Hernandez L, et al: Increased number of chromosomal imbalances and high-level DNA amplifications in mantle cell lymphoma are associated with blastoid variants. Blood 1999, 93(12):4365-74.

23. van de Vijver MJ, He YD, van't Veer $L$, Dai H, Hart AAM, Voskuil DW, et al: A gene-expression signature as a predictor of survival in breast cancer. $\mathrm{N}$ Engl J Med 2002, 347(25):1999-2009.

24. Costa VL, Henrique R, Ribeiro FR, Carvalho JR, Oliveira J, Lobo F, et al: Epigenetic regulation of Wnt signaling pathway in urological cancer. Epigenetics 2010, 5(4):343-51.

25. Deng G, Song G-A, Pong E, Sleisenger M, Kim YS: Promoter methylation inhibits APC gene expression by causing changes in chromatin conformation and interfering with the binding of transcription factor CCAAT-binding factor. Cancer research 2004, 64(8):2692-8.

26. Uesugi H, Uzawa K, Kawasaki K, Shimada K, Moriya T, Tada A, et al: Status of reduced expression and hypermethylation of the APC tumor suppressor gene in human oral squamous cell carcinoma. Int J Mol Med 2005, 15(4):597-602.

27. Jing $F$, Yuping $W$, Yong $C$, Jie $L$, Jun $L$, Xuanbing $T$, et al: $C p G$ island methylator phenotype of multigene in serum of sporadic breast carcinoma. Tumour Biol 2010, 31(4):321-31.

28. Boltze C, Hoang-Vu C, Schneider-Stock R, Lehnert H, Roessner A: [Role of the class II tumor suppressor gene maspin in thyroid carcinogenesis]. Verh Dtsch Ges Pathol 2004, 88:237-45. 
29. Yang N, Nijhuis ER, Volders HH, Eijsink JJ, Lendvai A, Zhang B, et al: Gene promoter methylation patterns throughout the process of cervical carcinogenesis. Cell Oncol 2010, 32(1-2):131-43.

30. Clement G, Braunschweig R, Pasquier N, Bosman FT, Benhattar J: Methylation of APC, TIMP3, and TERT: a new predictive marker to distinguish Barrett's oesophagus patients at risk for malignant transformation. J Pathol 2006, 208(1):100-7.

31. Kastan MB: Cell cycle. Checking two steps. Nature 2001, 410(6830):766-7.

32. Zhang P, Bhakta KS, Puri PL, Newbury RO, Feramisco JR, Wang JY: Association of ataxia telangiectasia mutated (ATM) gene mutation/ deletion with rhabdomyosarcoma. Cancer Biol Ther 2003, 2(1):87-91.

33. Leung WK, To K-F, Man EPS, Chan MWY, Bai AHC, Hui AJ, et al: Detection of epigenetic changes in fecal DNA as a molecular screening test for colorectal cancer: a feasibility study. Clin Chem 2004, 50(11):2179-82.

34. Safar AM, Spencer H, Su X, Coffey M, Cooney CA, Ratnasinghe LD, et al: Methylation profiling of archived non-small cell lung cancer: a promising prognostic system. Clin Cancer Res 2005, 11(12):4400-5.

35. Smith JA, Fan C-Y, Zou C, Bodenner D, Kokoska MS: Methylation status of genes in papillary thyroid carcinoma. Arch Otolaryngol Head Neck Surg 2007, 133(10):1006-11.

36. Vo QN, Kim W-J, Cvitanovic L, Boudreau DA, Ginzinger DG, Brown KD: The ATM gene is a target for epigenetic silencing in locally advanced breast cancer. Oncogene 2004, 23(58):9432-7.

37. Chim CS, Wong KY, Loong F, Srivastava G: Absence of ATM hypermethylation in mantle cell and follicular lymphoma. Leukemia 2005, 19(5):880-2.

38. Wong NC, Novakovic B, Weinrich B, Dewi C, Andronikos R, Sibson M, et al: Methylation of the adenomatous polyposis coli (APC) gene in human placenta and hypermethylation in choriocarcinoma cells. Cancer Lett 2008, 268(1):56-62

39. Kordi-Tamandani DM, Moazeni-Roodi AK, Rigi-Ladiz MA, Hashemi M, Birjandian E, Torkamanzehi A: Promoter hypermethylation and expression profile of MGMT and CDH1 genes in oral cavity cancer. Arch Oral Biol 2010, 55(10):809-14.

doi:10.1186/1868-7083-3-6

Cite this article as: Rigi-Ladiz et al.: Analysis of hypermethylation and expression profiles of APC and ATM genes in patients with oral squamous cell carcinoma. Clinical Epigenetics 2011 3:6.

\section{Submit your next manuscript to BioMed Central and take full advantage of:}

- Convenient online submission

- Thorough peer review

- No space constraints or color figure charges

- Immediate publication on acceptance

- Inclusion in PubMed, CAS, Scopus and Google Scholar

- Research which is freely available for redistribution

Submit your manuscript at www.biomedcentral.com/submit
C Biomed Central 